\title{
Polarographic Study of Iron-Benzoylacetonate in Dimethylformamide
}

\author{
by \\ Takeko INOUE \\ Department of Science Education, Nara University of Education, Takabatake-cho, Nara
}

(Recieved Nov. 7, 1968)

\begin{abstract}
Summary
The electrode process of $\mathrm{Fe}(\mathrm{BA})_{3}$ in $\mathrm{DMF}$ has been investigated by polarography and controlled potential electrolysis. The effects of water and acid on the behavior of $\mathrm{Fe}(\mathrm{BA})_{3}$ in DMF have been studied. $\mathrm{Fe}(\mathrm{BA})_{3}$ is reversibly reduced to $\mathrm{Fe}(\mathrm{BA})_{3}{ }^{-}$in $\mathrm{DMF}$ at a dropping mercury electrode in the presence of large excess of ligand. Addition of water affects the D.C. and A.C. wave heights and the half-wave potentials, but the electrode process is essentially identical with that in water free DMF. In acidic media, are observed several polarographic waves, which correspond to different species of iron-benzoylacetonates in the solution. From the polarographic data, the concentration of each species of the chelates can be determined and the consecutive formation constants of ironbenzoylacetonate have been calculated as $\log K_{1}=13.8, \log K_{2}=12.7$ and $\log K_{3}=10.9$. The acid dissociation constant of benzoylacetone in DMF determined by $\mathrm{pH}$ titration with a glass electrode is 13.2 .
\end{abstract}

\section{Introduction}

Polarography has been one of the most advantageous methods for the studies of chemical or electrochemical behaviors of metal chelate compounds in aqueous media. ${ }^{1)}$ Recently, however, some dipolar aprotic solvents such as acetonitrile, dimethylformamide (DMF) and dimethylsulfoxide have been used extensively as solvents for the polarographic studies of organic and inorganic compounds and many informations have been obtained on the mechanisms of the electrode processes. ${ }^{2)}$ These solvents would also be useful for the polarograhic studies of water-insoluble metal chelates, because they have reasonably large solubilities in these solvents.

As far as the metal $\beta$-diketone chelates are concerned, previous polarographic investigations have dealt mainly with metal acetylacetonates which are relatively soluble in water. Petek and Branica ${ }^{3)}$ and Cosovic and Branica ${ }^{4}$, for example, have studied the dissociation process of metal acetylacetonates in aqueous solution and have determined their consecutive formation constants polarographically. From analytical viewpoint, Dehn et al. ${ }^{5}$ could determine acetylacetonate of Be in water-chloroform-dimethylsulfoxide medium after extraction with chloroform. Afgahn et al. ${ }^{6)}$ also performed the solvent extraction of various metal ions with acetylacetone and determined In and Pd polarographically in toluene-ethanol system.

During the course of this study, Murray and Hiller ${ }^{7}$ have reported the effect of some cations on the electrode process of tris(acetylacetonato)-iron $\left(\mathrm{Fe}(\mathrm{AA})_{3}\right)$ in acetonitrile. 
They have found that the reduction wave of $\mathrm{Fe}(\mathrm{AA})_{3}$ is remarkably affected by the addition of lithium ion, because of the ion pair formation between the reduction product of $\mathrm{Fe}(\mathrm{AA})_{3}$ and lithium ion followed by ligand relaxation processes.

As the chemical behavior of metal chelate compounds are subject to the acidity of the solution, it seems worth-while to explain the effects of proton donors by taking into account the acidity of the solution. Few investigations in the solvents mentioned above, however, have been undertaken from such standpoint. In the present report, some electrochemical experiments have been conducted on the iron- $\beta$-diketone chelates in DMF, by taking into account the acidity of the solution to elucidate the effects of proton donors. $\mathrm{pH}$ in dipolar aprotic solvents can be defined as follows;

$$
\mathrm{pH}_{\mathrm{c}}=-\log \left[\mathrm{H}^{+}\right]
$$

where $\mathrm{pH}_{\mathrm{c}}$ is the $\mathrm{pH}$ represented by the concentration of the solvated proton. As Ritchie and Megerle $^{8)}$ have demonstrated, the $\mathrm{pH}_{\mathrm{c}}$ in $\mathrm{DMF}$ solution can be obtained by measuring with a $\mathrm{pH}$ meter the electromotive force of cell composed of a glass and a reference electrodes. The electromotive force changes by $59 \mathrm{mV}$ with a unit change of $\mathrm{pH}_{\mathrm{c}}{ }^{9}$. In the present report, a solution containing $10^{-2} M$ of perchloric acid, being completely dissociated in DMF, was used as a standard solution of $\mathrm{pH}_{\mathrm{c}}=2$ and the electromotive force was measured using an aqueous SCE as the reference electrode. $\mathrm{pH}_{\mathrm{c}}$ is then given as follows;

$$
\mathrm{pH}_{\mathrm{c}}=\left(E-E_{0}\right) / 59+2.0
$$

where $E$ and $E_{0}$ are the electromotive forces in the sample solution and the standard solution, respectively.

Thus, the electode process of tris(benzoylacetonato)-iron $\left(\mathrm{Fe}(\mathrm{BA})_{3}\right)$ at $\mathrm{DME}$ in $\mathrm{DMF}$ and the effects of proton donors on the electrode process and on the dissociation of $\mathrm{Fe}(\mathrm{BA})_{3}$ have been elucidated by means of polarography and controlled potential electrolysis. The consecutive stability constants of iron-benzoylacetonate in DMF have also been determined polarographically.

\section{Experimental}

Apparatus; A Yanagimoto polarograph PA-102 and a Yanagimoto Controlled Potential Electrolyzer were used. The iR drop was corrected for by measuring ohmic resistance of the solution with a conductance bridge. The electrolytic cell for polarographic measurement was an $\mathrm{H}$-type cell with a sintered glass between the two compartments. An aqueous saturated calomel electrode with an agar salt bridge was inserted in one compartment of the cell. $\mathrm{pH}_{\mathrm{c}}$ of the solution was measured with a conventional glass electrode, Horiba No. 1326, and an aqueous saturated calomel electrode with a tip of sintered glass disk. A pH meter of Hitachi-Horiba Co. Ltd. was used by connecting a potentiometer in series with the glass electrode system to apply bias voltage. The response of the glass electrode against $\mathrm{pH}_{\mathrm{c}}$ of the solution was checked with a picrate buffer solution in DMF. The potential of the glass electrode changed by $59 \mathrm{mV}$ for a unit change of $\log \mathrm{C}_{\mathrm{acid}} / \mathrm{C}_{\mathrm{salt}}$.

Reagents; Reagent grade DMF was dried over anhydrous sodium carbonate for a few days and purified twice by vacuum distillation. Tetraethylammoniumperchlorate $\left(\mathrm{Et}_{4} \mathrm{NClO}_{4}\right)$ was prepared following the method of Given ${ }^{10)}$. Ten percent tetraethylammoniumhydroxide $\left(\mathrm{Et}_{4} \mathrm{NOH}\right)$ of Wako Pure Chemicals Co. Ltd. and 70\%perchloric acid were used to control the acidity of the solution. Tris(benzoylacetonato)- 
iron $\left(\mathrm{Fe}(\mathrm{BA})_{3}\right)$ was prepared as follows; Benzoylacetone, which is in small excess to ferric iron was dissolved in warm ammoniacal ethanol and the resulting solution was added to an aqueous solution of ferric chloride. The dark red $\mathrm{Fe}(\mathrm{BA})_{3}$ began to separate immediately and precipitation was complete within a few minutes. The solution was cooled and added with water and then filtered. After being washed with water, the precipitate was air-dried at $50^{\circ} \mathrm{C}$ and dissolved in benzene. Pure $\mathrm{Fe}(\mathrm{BA})_{3}$ was crystallized from benzene solution by adding cyclohexane. Iron content of the chelate determined by phenanthroline method was $10.34 \%$ in good agreement with the theoretical value of $10.36 \%$. Benzoylacetone (HBA) was a guaranteed grade reagent of Wako Pure Chemicals Co. Ltd. and was used without further purification.

\section{Results}

\section{Polarographic behavior and stability of $\mathrm{Fe}(B A)_{3}$ in $D M F$.}

Polarographic behavior of $\mathrm{Fe}(\mathrm{BA})_{3}$ was studied in the presence of various concentrations of HBA. DMF solution containing $5 \times 10^{-4} M-\mathrm{Fe}(\mathrm{BA})_{3}, 0.1 M-\mathrm{Et}_{4} \mathrm{NGlO}_{4}$ and various concentrations of $\mathrm{HBA}$ were allowed to stand overnight and polarograms were recorded under nitrogen atmosphere. Relations between the polarographic properties of $\mathrm{Fe}(\mathrm{BA})_{3}$ and ligand concentrations are presented in Figs. 1 and 2.

If the concentration of $\mathrm{HBA}$ is more than five times larger than that of $\mathrm{Fe}(\mathrm{BA})_{3}$, $\mathrm{Fe}(\mathrm{BA})_{3}$ gives a single reduction wave whose half-wave potential is constant at $-0.62 \mathrm{~V}$ $v s$. SCE. independently of the concentration of HBA. The slope of the plot of $E v s$. $\log \left(i_{d}-i\right) / i$ is almost equal to the theoretical value for reversible one electron reduction. The A.C. polarographic reversibility constant $K$, which is defined by $K=\frac{i_{p}}{\mathrm{n} \sqrt{t} i_{d}}$, is approximately $95 \mathrm{~A}^{-1} \cdot \mho \cdot \mathrm{sec}^{-1 / 2}$ ( $K$ for the reversible reduction of $\mathrm{Tl}$ ion in aqueous $1 M-\mathrm{KNO}_{3}$ is 140), and the half-width of A.C. wave is $140 \mathrm{mV}$. In the presence of $3 \times 10^{-2}$ $M$-HBA, the height of D.C. wave of $\mathrm{Fe}(\mathrm{BA})_{3}$ increases linearly with its concentration in the range of $5 \times 10^{-5} M$ to $1 \times 10^{-3} M$. The D.C. wave height of $\mathrm{Fe}(\mathrm{BA})_{3}$ also changes linearly with the square root of mercuy column height and with the tempera-

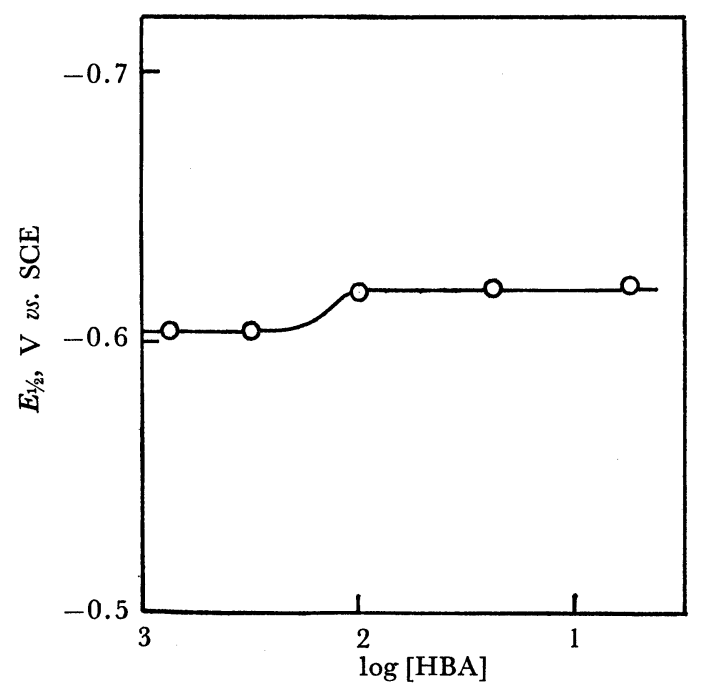

Fig. 1. Relation between the half-wave potential of $\mathrm{Fe}(\mathrm{BA})_{3}$ and concentration of HBA.

$5 \times 10^{-4} M-\mathrm{Fe}(\mathrm{BA})_{3}, 0.1 M-\mathrm{Et}_{4} \mathrm{NClO}_{4}$ in $\mathrm{DMF}$ 


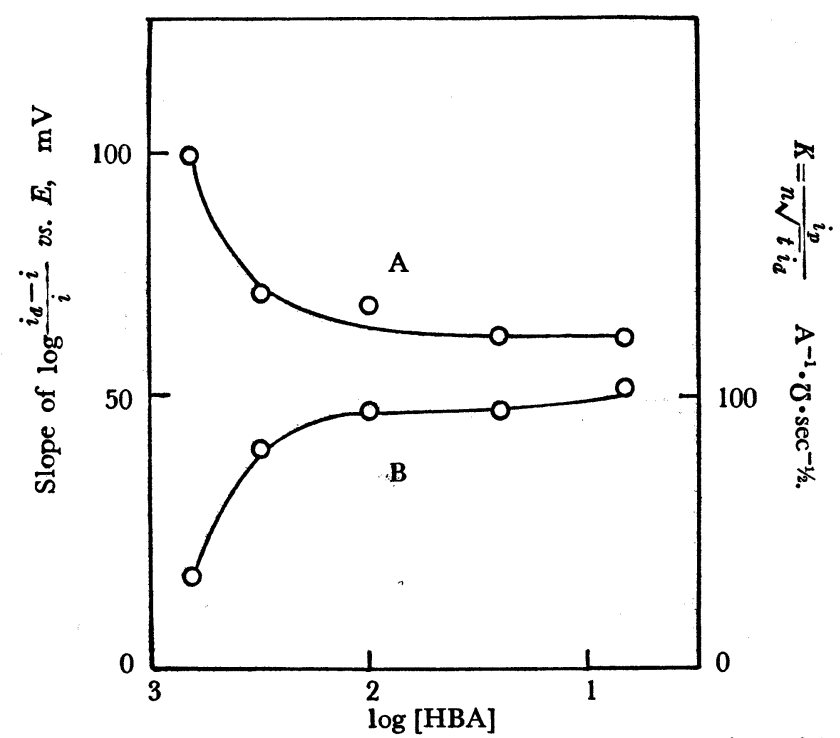

Fig. 2. Change of polarographic property with concentration of HBA $5 \times 10^{-4} M-\mathrm{Fe}(\mathrm{BA})_{3}, 0.1 M-\mathrm{Et}_{4} \mathrm{NGlO}_{4}$ in $\mathrm{DMF}$.

Curve A : slope of $\log \frac{i_{d}-i}{i} v s$. " $E$, Curve B : K.

ture of the solution. The temperature coefficient is $1.0 \% /{ }^{\circ} \mathrm{C}$. From these results, the polarographic wave of $\mathrm{Fe}(\mathrm{BA})_{3}$ seems to be diffusion controlled. The diffusion current constant of $\mathrm{Fe}(\mathrm{BA})_{3}$ in $\mathrm{DMF}$ is $2.60 \mu \mathrm{A} \cdot \mathrm{sec}^{1 / 2} \cdot l \cdot \mathrm{m} M^{-1} \cdot \mathrm{mg}^{-2 / 3}$.

If there is no excess ligand in the solution, $\mathrm{Fe}(\mathrm{BA})_{3}$ gives two irreversible polarographic wave at $-0.60 \mathrm{~V}$ and $-1.1 \mathrm{~V}$ vs. SCE, respectively. The wave at more negative potential seems to be due to the reduction of the species partially decomposed from $\mathrm{Fe}(\mathrm{BA})_{3}$ by solvolysis. $\mathrm{Fe}(\mathrm{BA})_{3}$ is decomposed gradually in DMF. The red color of the chelate fades with time and finally, after two days, brown precipitate appears. From these results, it can be concluded that $\mathrm{Fe}(\mathrm{BA})_{3}$ is stable in DMF only in the presence of large excess of HBA and gives almost reversible, diffusion controlled polarographic wave.

In a cell of $100 \mathrm{~m} l$ beaker, $50 \mathrm{~m} l$ of the solution containing $5 \times 10^{-4} M-\mathrm{Fe}(\mathrm{BA})_{3}, 3 \times$ $10^{-2} M$-HBA and $0.1 M-\mathrm{Et}_{4} \mathrm{NClO}_{4}$ was electrolyzed by controlling the potential of $\mathrm{Hg}$

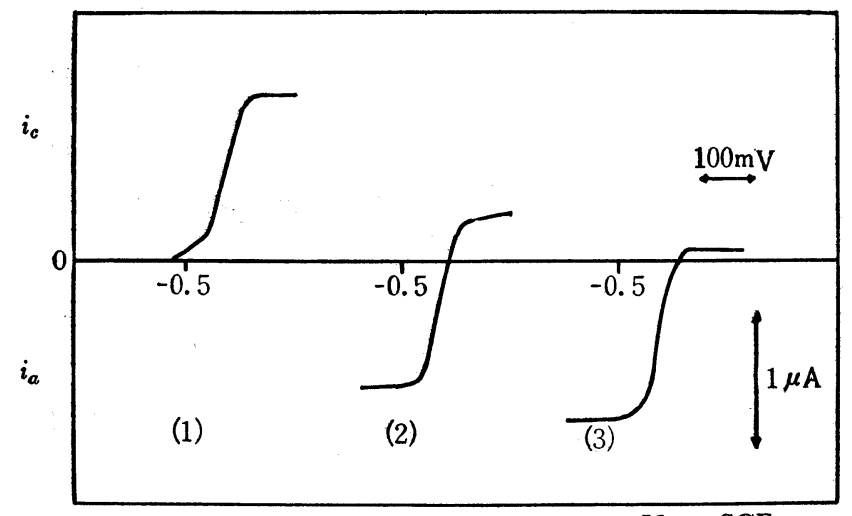

$\mathrm{V}$ vs. SCE

Fig. 3. Polarograms during controlled potential electrolysis. $5 \times 10^{-4} M-\mathrm{Fe}(\mathrm{BA})_{3}, 3 \times 10^{-2} M-\mathrm{HBA}, 0.1 M-\mathrm{Et}_{4} \mathrm{NGlO}_{4}$ in DMF. Electrolysis time $1 ; 0,2 ; 21,3 ; 87$, min. 


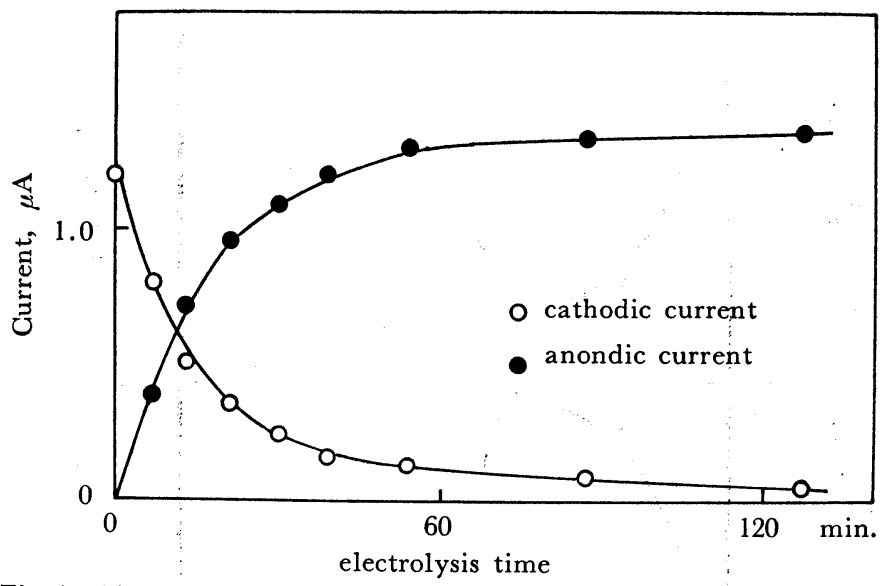

Fig. 4. Change of wave heights with electrolysis time. $5 \times 10^{-4} M-\mathrm{Fe}(\mathrm{BA})_{3}, 3 \times 10^{-2} M-\mathrm{HBA}, 0.1 M-\mathrm{Et}_{4} \mathrm{NGlO}_{4}$.

pool (surface area $12.6 \mathrm{~cm}^{2}$ ) at $-0.75 \mathrm{~V} v s$. SCE. The color of the solution changed from red $\left(\lambda_{\max }=450 \mathrm{~m} \mu\right)$ to purple $\left(\lambda_{\max }=490 \mathrm{~m} \mu\right)$ as electrolysis went on. During the course of controlled potential electrolysis, the DME and the SCE were inserted into the solution under electrolysis and polarograms were recorded. Composite redox waves as in Fig. 3 were obtained. As is shown in Fig. 4, when the electrolysis proceeded, the oxidation current increased at the expense of the reduction current, the total wave height being maintained almost constant. The height of oxidation wave reaches a constant value after long period of electrolysis, indicating that the reduction product of $\mathrm{Fe}(\mathrm{BA})_{3}$ is reasonably stable in DMF.

From the results of polarography and controlled potential electrolysis, it is found that the electrode reaction of $\mathrm{Fe}(\mathrm{BA})_{3}$ in $\mathrm{DMF}$ proceeds by the following equation producing stable $\mathrm{Fe}(\mathrm{BA})_{3}{ }^{-}$ions ;

$$
\mathrm{Fe}(\mathrm{BA})_{3}+\mathrm{e} \rightleftharpoons \mathrm{Fe}(\mathrm{BA})_{3}{ }^{-}
$$

2. Effects of water on the polarographic properties of $F e(B A)_{3}$.

The change of the polarographic properties of $\mathrm{Fe}(\mathrm{BA})_{3}$ with the addition of water is given in Fig. 5. The heights of A.C. and D.C. waves decrease with the increase of water content in the solution, but the value of the product of the D.C. wave height and the square root of the viscosity of the solvent is constant from 0 to $40 \mathrm{vol} . \%$ of water. Therefore, the decrease in D.C. wave height seems to be due to the increase of the viscosity of the solution. The rapid decrease of the A.C. wave height with the addition of water is probably due to the decrease of the reversibility of the electrode reaction.

Polarograms recorded with the solution under controlled potential electrolysis at $-0.75 \mathrm{~V} v s$. SCE. gave a composite redox wave in the presence of various concentrations of water and the half-wave potentials of the redox waves were identical with those of the reduction wave of $\mathrm{Fe}(\mathrm{BA})_{3}$. From these, the electrode process of $\mathrm{Fe}(\mathrm{BA})_{3}$ in waterDMF system seems to be essentially identical with that in water-free DMF. The halfwave potentials shift to more positive direction with the increase of water. The change of the properties of the solution, such as the acidity and the dielectric constant might be responsible for this shift, but available data are not sufficient to explain the shift quantitatively. Effects of water on the polarographic properties of $\mathrm{Fe}(\mathrm{BA})_{3}$ is not large when the water content is less than 1 vol. $\%$, so the effect of small amount 


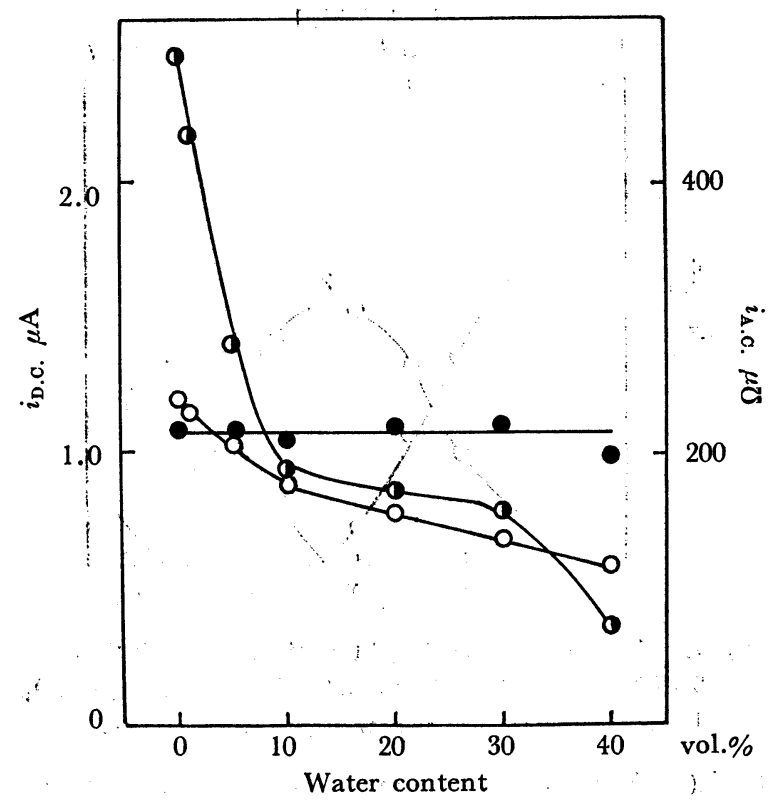

Fig. 5. Effect of water on the wave height of $\mathrm{Fe}(\mathrm{BA})_{3}$. $5 \times 10^{-4} M-\mathrm{Fe}(\mathrm{BA})_{3}, 3 \times 10^{-2} M-\mathrm{HBA}, 0.1 M-\mathrm{Et}_{4} \mathrm{NGlO}_{4}$. (1) $i_{\mathrm{A} . \mathrm{c} .} \bigcirc i_{\mathrm{D} . \mathrm{c} .} \bigcirc i_{\mathrm{D} . \mathrm{c} .} \cdot \eta^{1 / 2}$

of water which is introduced when $70 \% \mathrm{HClO}_{4}$ is added to control the acidity of the solution may be negligible.

3. Behavior of $\mathrm{Fe}(B A)_{3}$ in the presence of acid.

3.1. Dissociation of $\mathrm{Fe}(\mathrm{BA})_{3}$ in the acidic media.

The behavior of $\mathrm{Fe}(\mathrm{BA})_{3}$ in the presence of various concentrations of perchloric acid was polarographically investigated. D.C. polarograms of the solution containing $5 \times 10^{-4}$. $M$-Fe(BA) $)_{3}, 3 \times 10^{-2} M-\mathrm{HBA}$ and $0.1 M-\mathrm{Et}_{4} \mathrm{NGlO}_{4}$ varied with the concentration of $\mathrm{HClO}_{4}$ as shown in Fig. 6. When the concentration of $\mathrm{HClO}_{4}$ is smaller than $2 \times 10^{-4} M$, $\mathrm{Fe}(\mathrm{BA})_{3}$ gives a reversible wave at $-0.63 \mathrm{~V}$ vs. $\mathrm{SCE}$, which is identical with the wave of $\mathrm{Fe}(\mathrm{BA})_{3}$ in acid-free $\mathrm{DMF}$ solution. In the range of $3 \times 10^{-4} \mathrm{M}$ to $5 \times 10^{-2} \mathrm{M} \mathrm{HClO}_{4}$,

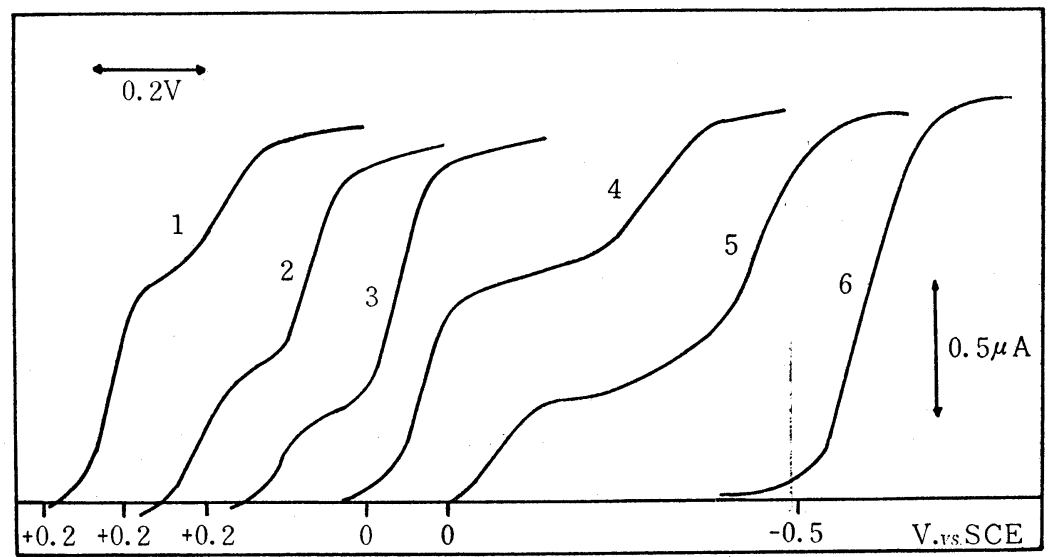

Fig. 6. Polarograms of $\mathrm{Fe}(\mathrm{BA})_{3}$ in the presence of $\mathrm{HClO}_{4} .5 \times 10^{-4} \mathrm{M}-\mathrm{Fe}(\mathrm{BA})_{3}$, $3 \times 10^{-2} M-\mathrm{HBA}, 0.1 M-\mathrm{Et}_{4} \mathrm{NGlO}_{4}$. Concn. of $\mathrm{HClO}_{4} 1: 2.5 \times 10^{-2} M, 2: 1 \times$ $10^{-2} M, 3: 5 \times 10^{-3} M, 4: 1 \times 10^{-3} M, 5: 5 \times 10^{-4} M, 6: 1 \times 10^{-4} M$. 


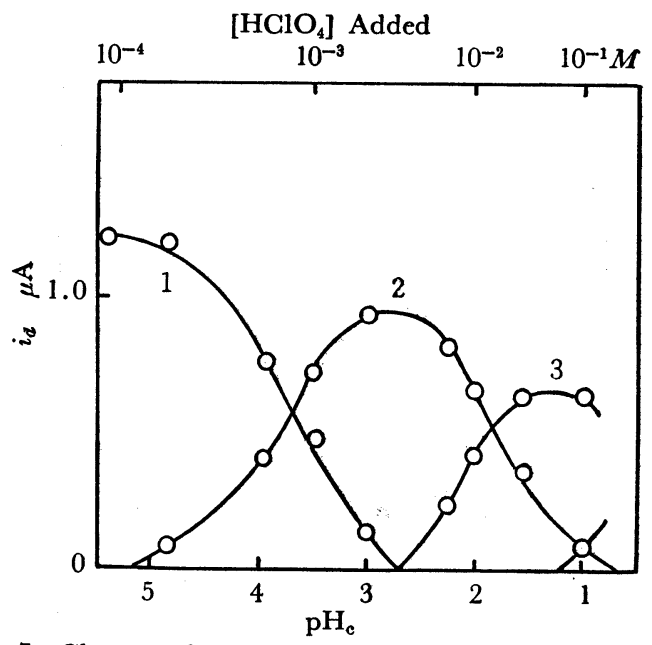

Fig. 7. Change of wave height with $\mathrm{pH}$ of solution. $5 \times 10^{-4} M-\mathrm{Fe}(\mathrm{BA})_{3}, 3 \times 10^{-2} M-\mathrm{HBA}, 0.1 M-\mathrm{Et}_{4} \mathrm{NClO}_{4}$. 1 ; first wave, 2 ; second wave, 3 ; third wave.

the polarograms of $\mathrm{Fe}(\mathrm{BA})_{3}$ split into two waves whose half-wave potentials are about $-0.55 \mathrm{~V}$ and $-0.1 \mathrm{~V}$ vs. SCE, respectively. The height of the first wave (more negative wave) decreases with the increase of the acid concentration, whereas that of the second wave (more positive wave) increases. In more concentrated acid solution, a new wave appears at more positive potential, approximately $+0.2 \mathrm{~V} v$ s. SCE, and the first wave disappears. The height of the second wave decreases with the increase of the acid concentration, while that of the third (most positive wave) increases. All of these waves are diffusion-controlled. Therefore, each wave height seems to indicate the concentration of each species in the solution. The first wave corresponds to the reduction of $\mathrm{Fe}(\mathrm{BA})_{3}$ and the second and the third waves seem to be due to the reduction of $\mathrm{Fe}$ $(\mathrm{BA})_{2}{ }^{+}$and $\mathrm{Fe}(\mathrm{BA})^{2+}$, respectively. The $\mathrm{pH}_{\mathrm{c}}$ of the solution was measured using a glass electrode and the change of each wave with $\mathrm{pH}_{\mathrm{c}}$ was obtained. The results are given in Fig. 7. The $\mathrm{pH}_{\mathrm{c}}$ of the solution varied linearly at a rate predicted theoretically with the logarithm of the acid concentration between $2 \times 10^{-3} M$ and $10^{-1} M$, but when the concentration of the acid was smaller than $10^{-3} M, \mathrm{pH}_{\mathrm{c}}$ of the solution increased more abruptly with the decrease of acid concentration. It is probably due to the buffer action of dimethylamine which might be present in DMF. From Fig. 7, $\mathrm{Fe}(\mathrm{BA})_{3}$ seems to be dissociated as in Table 1 with the change of $\mathrm{pH}_{\mathrm{c}}$ of the solution.

Table 1. Scheme of dissociation reaction of $\mathrm{Fe}(\mathrm{BA})_{3}$, $5 \times 10^{-4} M-\mathrm{Fe}(\mathrm{BA})_{3}, 3 \times 10^{-2} M-\mathrm{HBA}, 0.1 M-\mathrm{Et}_{4} \mathrm{NClO}_{4}$

\begin{tabular}{c|l|c}
\hline \multicolumn{1}{c|}{$\mathrm{pH}_{\mathrm{c}}$} & \multicolumn{1}{|c}{ Dissociation reaction } & Predominant species \\
\hline $\mathrm{pH}_{\mathrm{c}}>5$ & & \multicolumn{1}{|c}{$\mathrm{Fe}(\mathrm{BA})_{3}$} \\
$5>\mathrm{pH}_{\mathrm{c}}>2.5$ & $\mathrm{Fe}(\mathrm{BA})_{3}+\mathrm{H}^{+} \rightleftarrows \mathrm{Fe}(\mathrm{BA})_{2}{ }^{+}+\mathrm{HBA}$ & $\mathrm{Fe}(\mathrm{BA})_{3}, \mathrm{Fe}(\mathrm{BA})_{2}{ }^{+}$ \\
$2.5>\mathrm{pH}_{\mathrm{c}}>1$ & $\mathrm{Fe}(\mathrm{BA})_{2}^{+}+\mathrm{H}^{+} \rightleftarrows \mathrm{Fe}(\mathrm{BA})^{2+}+\mathrm{HBA}$ & $\mathrm{Fe}(\mathrm{BA})_{2}^{+}, \mathrm{Fe}(\mathrm{BA})^{2+}$ \\
$1>\mathrm{pH}_{\mathrm{c}}$ & $\mathrm{Fe}(\mathrm{BA})^{2+}+\mathrm{H}^{+} \rightleftarrows \mathrm{Fe}^{3+}+\mathrm{HBA}$ & $\mathrm{Fe}(\mathrm{BA})^{2+}, \mathrm{Fe}^{3+}$ \\
\hline
\end{tabular}

3.2. Electrode reaction of $\mathrm{Fe}(\mathrm{BA})_{3}$ in the presence of acid.

Linear relations are obtained between the half-wave potentials of each polarographic wave and the $\mathrm{pH}_{\mathrm{c}}$ of the solution, if $\mathrm{pH}_{\mathrm{c}}$ is smaller than 5 as in Fig. 8. This 


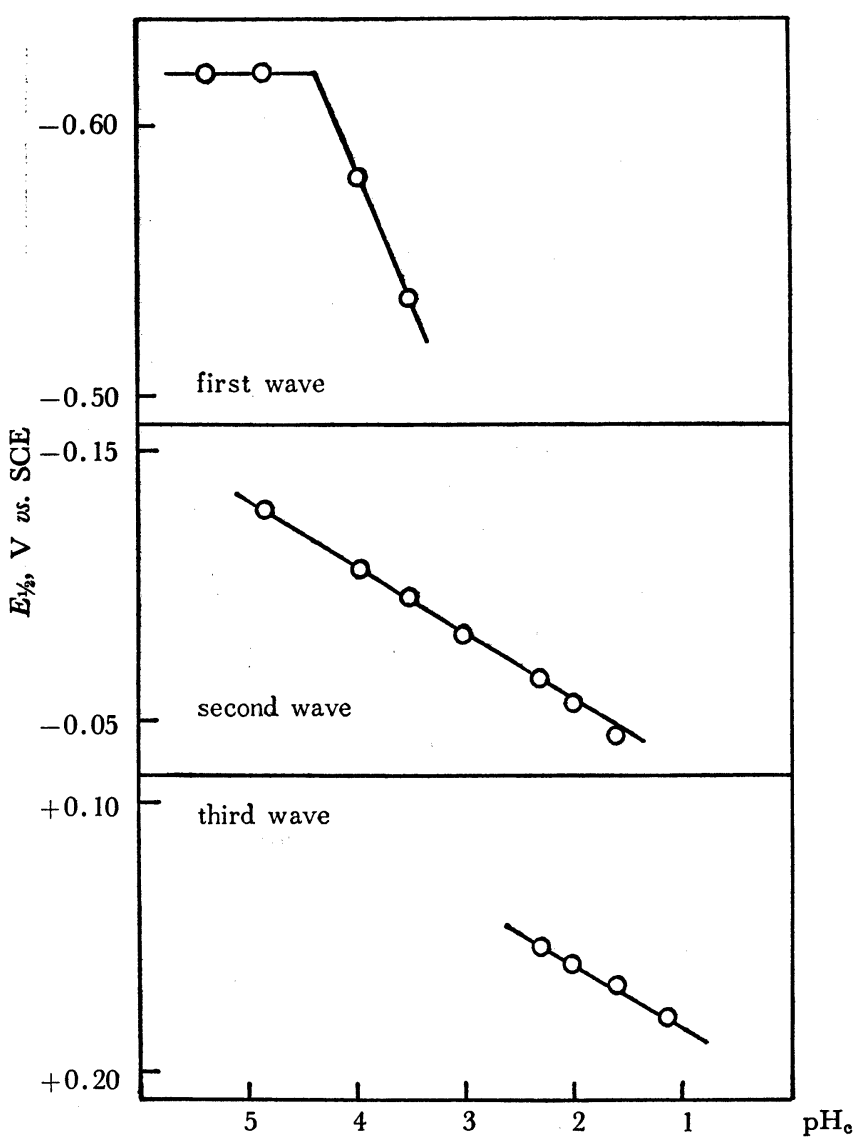

Fig. 8. Relation between half-wave potentials and $\mathrm{pH}_{\mathrm{c}}$ of solution. $5 \times 10^{-4} M-\mathrm{Fe}(\mathrm{BA})_{3}, 3 \times 10^{-2} M-\mathrm{HBA}, 0.1 M-\mathrm{Et}_{4} \mathrm{NClO}_{4}$

shows that proton might take part in the electrode process of iron-benzoylacetonate. The changes of the half-wave potentials for a unit change of $\mathrm{pH}_{\mathrm{c}}$ are $90 \mathrm{mV}$ for the first wave and $25 \mathrm{mV}$ for the second and the third waves, respectively. Solutions consisting of $5 \times 10^{-4} M-\mathrm{F} \epsilon(\mathrm{BA})_{3}, 3 \times 10^{-2} M-\mathrm{HBA}, 0.1 M-\mathrm{Et}_{4} \mathrm{NClO}_{4}$ and various concentrations of $\mathrm{HClO}_{4}$ were electrolyzed at controlled potentials using $\mathrm{Hg}$-pool electrode and the reduction products were investigated by measuring the change of polarograms in the solutions under controlled potential electrolysis.

$\mathrm{pH}_{\mathrm{c}}>5$ : In the presence of $1 \times 10^{-4} \mathrm{M}-\mathrm{HClO}_{4}$, the solution was electrolyzed at the cathode potential of $-0.75 \mathrm{~V}$ vs. SCE and, during the electrolysis, the change of the polarographic behavior of the solution was traced. In any stage of the electrolysis, a composite anodic-cathodic wave was obtained at $-0.62 \mathrm{~V} v s$. SCE, though the anodic current increased with time at the expense of the cathodic current. This shows that the reduction product $\mathrm{Fe}(\mathrm{BA})_{3}{ }^{-}$is stable and reversibly oxidized and that a proton does not take part in the reaction. This is also supported by the relation between the halfwave potential and the $\mathrm{pH}_{\mathrm{c}}$ of the solution in Fig. 8 .

$5>\mathrm{pH}_{\mathrm{c}}>2.5:$ At $\mathrm{pH}_{\mathrm{c}} 3.5$, there are two species in the solution; namely, $\mathrm{Fe}(\mathrm{BA})_{3}$ and $\mathrm{Fe}(\mathrm{BA})_{2}{ }^{+}$. The half-wave potentials of the reduction waves of these species are $-0.53 \mathrm{~V}$ and $-0.10 \mathrm{~V}$ vs. SCE, respectively. Using the mercury pool working electorde, the solution was first electrolyzed at the potential of $-0.25 \mathrm{~V}$, so that only $\mathrm{Fe}(\mathrm{BA})_{2}{ }^{+}$would 


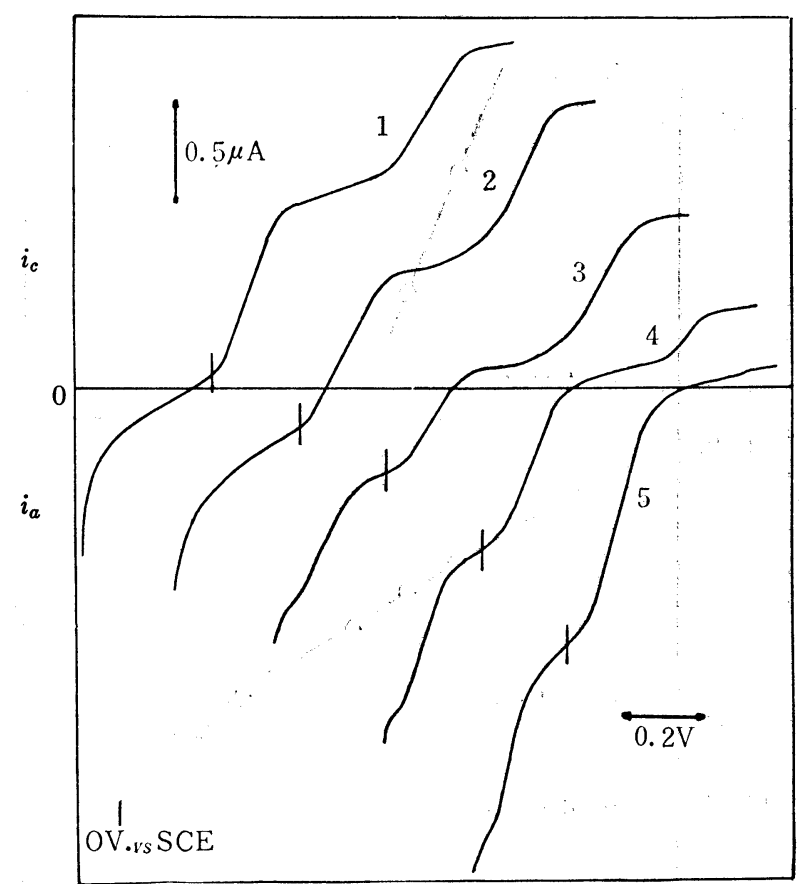

Fig. 9. Change of polarograms during controlled potential electrolysis in acidic media.

$5 \times 10^{-4} M-\mathrm{Fe}(\mathrm{BA})_{3}, 3 \times 10^{-2} M-\mathrm{HBA}, 0.1 M-\mathrm{Et}_{4} \mathrm{NClO}_{4}$. $\mathrm{pH}_{\mathrm{c}}=3.5$. Set potential $1 \sim 3,-0.25 \mathrm{~V}, 4 \sim 5,-0.75 \mathrm{~V}$ os. SGE.,

be electrolyzed. After the polarographic reduction wave of $\mathrm{Fe}(\mathrm{BA})_{2}{ }^{+}$had disappeared, the cathode potential was switched to $-0.75 \mathrm{~V}$ and the electrolysis was carried on. Polarograms obtained in the solution under controlled potential electrolysis are presented in Fig. 9. By electrolysis at $-0.25 \mathrm{~V}, \mathrm{Fe}(\mathrm{BA})_{2}{ }^{+}$was reduced and the reduction products gave oxidation waves at $+0.15 \mathrm{~V}$ and $-0.10 \mathrm{~V}$ vs. SCE, respectively. The wave at $-0.10 \mathrm{~V}$ is a composite redox wave due to the reduction of $\mathrm{Fe}(\mathrm{BA})_{2}{ }^{+}$and the oxidation of its reduced form. The more positive wave at $+0.15 \mathrm{~V}$ seems to be the oxidation wave of $\mathrm{Fe}(\mathrm{BA})^{+}$which was produced by the acid dissociation of $\mathrm{Fe}(\mathrm{BA})_{2}$. Thus, the reaction mechanism can be concluded as follows; $\mathrm{Fe}(\mathrm{BA})_{2}$ is reduced by eq. (1) to $\mathrm{Fe}(\mathrm{BA})_{2}$, which is in equilibrium with $\mathrm{Fe}(\mathrm{BA})^{+}$as shown by eq. (2).

$$
\begin{aligned}
& \mathrm{Fe}(\mathrm{BA})_{2}{ }^{+}+\mathrm{e} \rightleftharpoons \mathrm{Fe}(\mathrm{BA})_{2} \\
& \mathrm{Fe}(\mathrm{BA})_{2}+\mathrm{H}^{+} \rightleftharpoons \mathrm{Fe}(\mathrm{BA})^{+}+\mathrm{HBA}
\end{aligned}
$$

The heights of the oxidation waves of $\mathrm{Fe}(\mathrm{BA})_{2}$ and $\mathrm{Fe}(\mathrm{BA})^{+}$have a tendency to decrease in a long period of electrolysis. This may be due to the partial decomposition of the reduction products. After $\mathrm{Fe}(\mathrm{BA})_{2}{ }^{+}$had been completely reduced, the cathode potential was settled to $-0.75 \mathrm{~V}$ vs. $\mathrm{SCE}$. and $\mathrm{Fe}(\mathrm{BA})_{3}$ was electrolyzed. The anodic oxidation waves at $-0.10 \mathrm{~V}$ and $+0.15 \mathrm{~V}$ increased in heights but no oxidation wave was observed at $-0.62 \mathrm{~V}$ vs. SCE. This indicates that the reduction of $\mathrm{Fe}(\mathrm{BA})_{3}$ at this $\mathrm{pH}_{\mathrm{c}}$ occurs as follows; $\mathrm{Fe}(\mathrm{BA})_{2}$ is formed by eqs. (3) and (4).

$$
\begin{aligned}
& \mathrm{Fe}(\mathrm{BA})_{3}+\mathrm{e} \rightarrow \mathrm{Fe}(\mathrm{BA})_{3}^{-} \\
& \mathrm{Fe}(\mathrm{BA})_{3}^{-}+\mathrm{H}^{+} \rightarrow \mathrm{Fe}(\mathrm{BA})_{2}+\mathrm{HBA}
\end{aligned}
$$

then, $\mathrm{Fe}(\mathrm{BA})_{2}$ is in equilibrium with $\mathrm{Fe}(\mathrm{BA})^{+}$as shown by eq. (2).

$$
\mathrm{Fe}(\mathrm{BA})_{2}+\mathrm{H}^{+} \rightleftharpoons \mathrm{Fe}(\mathrm{BA})^{+}+\mathrm{HBA}
$$




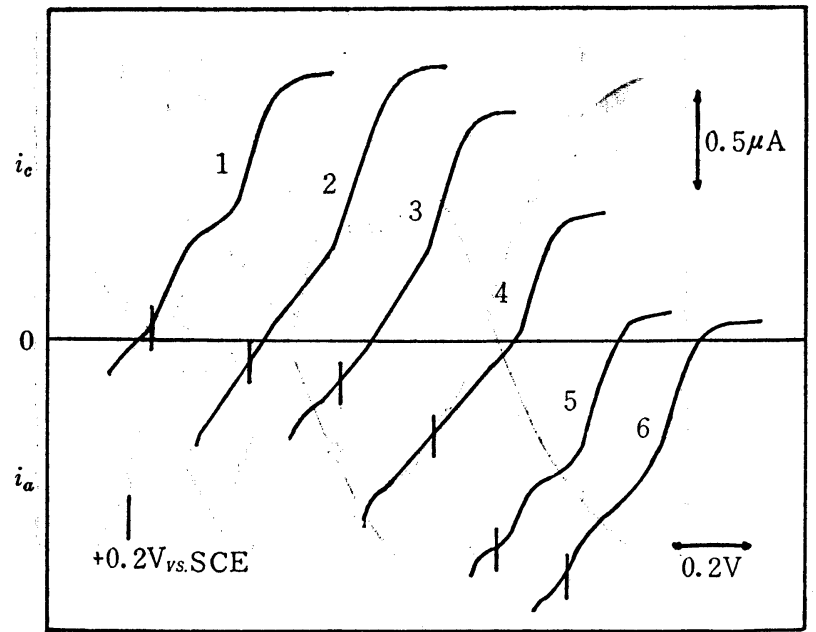

Fig. 10. Change of polarograms during controlled potential electrolysis in acidic media. $5 \times 10^{-4} M-\mathrm{Fe}(\mathrm{BA})_{3}, 3 \times 10^{-2} M-\mathrm{HBA}, 0.1 M-\mathrm{Et}_{4} \mathrm{NClO}_{4}$, $\mathrm{pH}=2$. Set potential ; 1 3, +0.05V, 4 6, $-0.25 \mathrm{~V}$ vs. SCE.

2.5 $>\mathrm{pH}_{\mathrm{c}}>\mathrm{l}: \mathrm{At}_{\mathrm{pH}}$ 2, the reduction waves of $\mathrm{Fe}(\mathrm{BA})^{2+}$ and $\mathrm{Fe}(\mathrm{BA})_{2}{ }^{+}$are found at $+0.16 \mathrm{~V}$ and $-0.06 \mathrm{~V}$ vs. SCE, respectively. Controlled potential electrolysis was carried out by setting the cathode potential first at $+0.05 \mathrm{~V}$ and then at $-0.25 \mathrm{~V}$. Polarograms obtained in the course of electrolysis are presented in Fig. 10. As the reduction of $\mathrm{Fe}(\mathrm{BA})^{2+}$ at $+0.05 \mathrm{~V}$ goes on, a composite redox wave appears at $+0.16 \mathrm{~V}$, but the wave is ill-shaped and the height of the reduction wave of $\mathrm{Fe}(\mathrm{BA})_{2}{ }^{+}$ increases although only temporarily at the beginning of the electrolysis. This is probably due to a chemical reaction taking place between the reduction product and the solution in the course of the electrolysis. The following mechanism would be proposed as the electrode process and the successive chemical process.

Electrode reaction : $\quad \mathrm{Fe}(\mathrm{BA})^{2+}+\mathrm{e} \rightleftharpoons \mathrm{Fe}(\mathrm{BA})^{+}$

$$
\mathrm{Fe}(\mathrm{BA})^{+}+\mathrm{H}^{+} \rightleftharpoons \mathrm{Fe}^{2+}+\mathrm{HBA}
$$

Chemical reaction : $\mathrm{Fe}(\mathrm{BA})^{2+}+\mathrm{Fe}(\mathrm{BA})^{+} \rightleftharpoons \mathrm{Fe}(\mathrm{BA})_{2}{ }^{+}+\mathrm{Fe}^{2+}$

Similar reactions have been proposed by Murray and Hiller for tris (acetylacetonato) iron system in acetonitrile. As the electrolysis proceeds and the concentration of $\mathrm{Fe}(\mathrm{BA})^{2+}$ in the solution decreases, the successive chemical reaction becomes difficult and the height of the reduction wave of $\mathrm{Fe}(\mathrm{BA})_{2}{ }^{+}$does not increase any more. After the electrolysis of $\mathrm{Fe}(\mathrm{BA})^{2+}$ had been completed, the cathode potential was set at $-0.25 \mathrm{~V}$ and $\mathrm{Fe}(\mathrm{BA})_{2}{ }^{+}$was electrolyzed. A cathodic wave at $-0.06 \mathrm{~V}$ disappeared and the oxidation wave at $+0.16 \mathrm{~V}$ increased in height. From these results, the electrode reaction of $\mathrm{Fe}(\mathrm{BA})_{2}{ }^{+}$seems as follows :

$$
\begin{aligned}
\mathrm{Fe}(\mathrm{BA})_{2}{ }^{+}+\mathrm{e} \rightleftharpoons & \mathrm{Fe}(\mathrm{BA})_{2} \\
& \mathrm{Fe}(\mathrm{BA})_{2}+\mathrm{H}^{+} \rightleftharpoons \mathrm{Fe}(\mathrm{BA})^{+}+\mathrm{HBA}
\end{aligned}
$$

4. Polarographic determination of consecutive formation constants of iron-benzoylacetonate in DMF.

In section 3.1, iron-benzoylacetonate was found to show three diffusion controlled waves which correspond to three kinds of chelate species present in the solution. These phenomena are available to determine the consecutive formation constants of ironbenzoylacetonate in DMF. In this experiment, higher concentration of ligand is used 


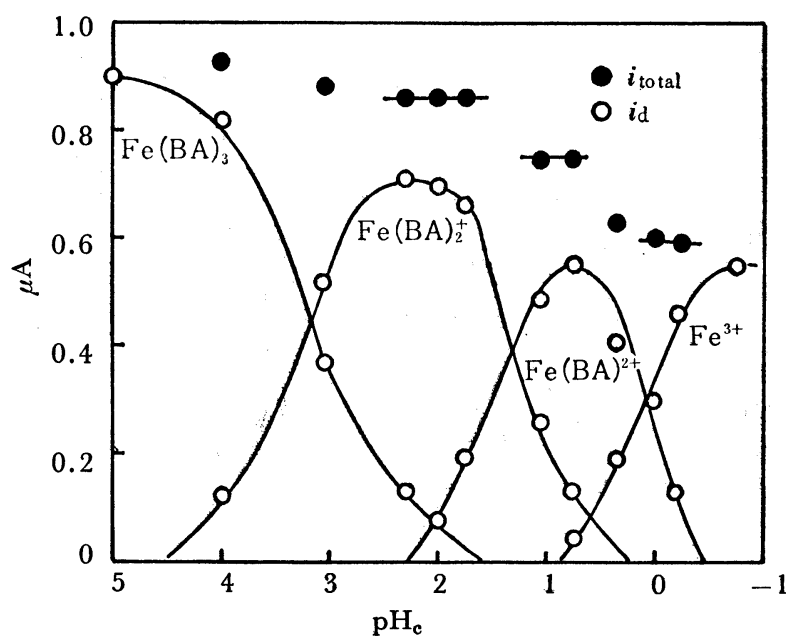

Fig. 11. Change of wave height of each chelate with $\mathrm{pH}$ of solution. $5 \times 10^{-4} M-\mathrm{Fe}(\mathrm{BA})_{3}, 0.15 M-\mathrm{HBA}, 0.1 M-\mathrm{Et}_{4} \mathrm{NGlO}_{4}$.

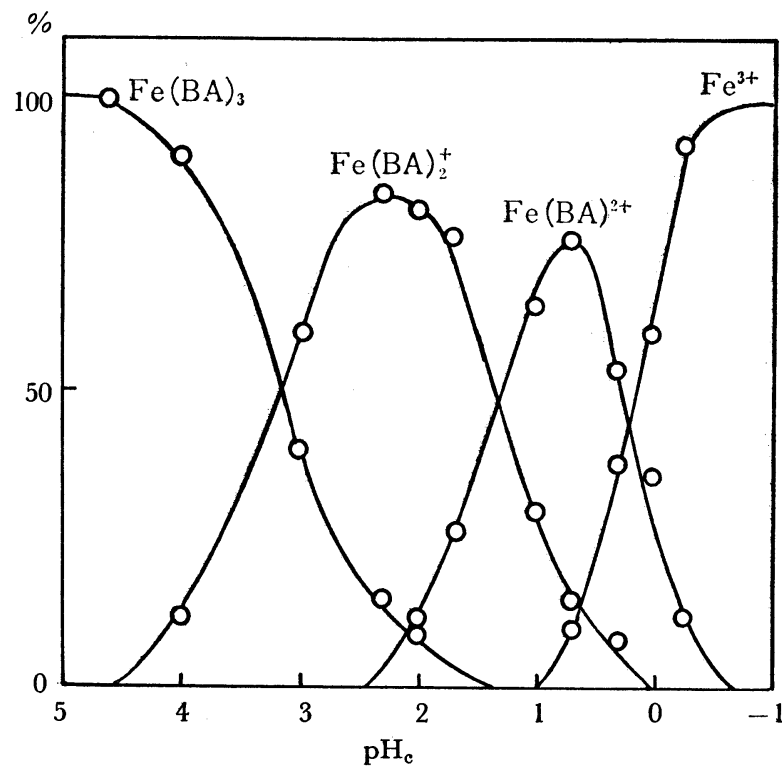

Fig. 12. Change of molar fraction of each chelate with $\mathrm{pH}$ of solution. $5 \times 10^{-4} M-\mathrm{Fe}(\mathrm{BA})_{3}, 0.15 M-\mathrm{HBA}, 0.1 M-\mathrm{Et}_{4} \mathrm{NGlO}_{4}$.

so that the dissociation of $\mathrm{Fe}(\mathrm{BA})_{3}$ takes place in the lower $\mathrm{pH}$ region where the buffer action of the solution is larger. A solution containing $0.15 M-\mathrm{HBA}, 5 \times 10^{-4} M-\mathrm{Fe}(\mathrm{BA})_{3}$, $0.1 M-\mathrm{Et}_{4} \mathrm{NClO}_{4}$ gives four different polarographic waves in the range of $5>\mathrm{pH}_{\mathrm{c}}>-1$. Change of the height of each wave is shown in Fig. 11. From this figure, it is concluded that four species, that is, $\mathrm{Fe}(\mathrm{BA})_{3}, \mathrm{Fe}(\mathrm{BA})_{2}{ }^{+}, \mathrm{Fe}(\mathrm{BA})^{2+}, \mathrm{Fe}^{3+}$ are present in the acidic media. The height of total wave is not constant over the whole $\mathrm{pH}$ range, but decreases with the increase of the acidity of the solution probably because the diffusion coefficient decreases with the decrease of the number of $\mathrm{BA}$ chelated to $\mathrm{Fe}^{++}$. By assuming that the diffusion coefficient of each species does not change with $\mathrm{pH}$, the concentration of $\mathrm{Fe}(\mathrm{BA})_{3}, \mathrm{Fe}(\mathrm{BA})_{2}{ }^{+}, \mathrm{Fe}(\mathrm{BA})^{2+}, \mathrm{Fe}^{3+}$ could be calculated from Fig. 11 as 
the function of $\mathrm{pH}$. The results are given in Fig. 12. Consecutive formation constants could be estimated using these values and the acid dissociation constant of benzoylacetone in DMF. The acid dissociation constant of benzoylacetone and the consecutive formation constants of iron-benzoylacetonate can be written as;

$$
\begin{array}{lc}
\mathrm{HBA}^{\stackrel{K_{\mathrm{a}}}{\rightleftharpoons} \mathrm{H}^{+}+\mathrm{BA}^{-}} \quad K_{\mathrm{a}}=\frac{\left[\mathrm{H}^{+}\right]\left[\mathrm{BA}^{-}\right]}{[\mathrm{HBA}]} \\
\mathrm{Fe}^{3+}+\mathrm{BA}^{-} \stackrel{K_{1}}{\rightleftharpoons} \mathrm{Fe}(\mathrm{BA})^{2+} & K_{1}=\frac{\left[\mathrm{Fe}(\mathrm{BA})^{2+}\right]}{\left[\mathrm{Fe}^{3+}\right]\left[\mathrm{BA}^{-}\right]} \\
\mathrm{Fe}(\mathrm{BA})^{2+}+\mathrm{BA}^{-} \stackrel{K_{2}}{\rightleftharpoons} \mathrm{Fe}(\mathrm{BA})_{2}{ }^{+} & K_{2}=\frac{\left[\mathrm{Fe}(\mathrm{BA})_{2}^{+}\right]}{\left[\mathrm{Fe}(\mathrm{BA})_{2}{ }^{+}\right]\left[\mathrm{BA}^{-}\right]} \\
\mathrm{Fe}(\mathrm{BA})_{2}^{+}+\mathrm{BA}^{-} \stackrel{K_{3}}{\rightleftharpoons} \mathrm{Fe}(\mathrm{BA})_{3} & K_{3}=\frac{\left[\mathrm{Fe}(\mathrm{BA})_{3}\right]}{\left[\mathrm{Fe}(\mathrm{BA})_{2}{ }^{+}\right]\left[\mathrm{BA}^{-}\right]} \\
K_{i}=\frac{\left[\mathrm{Fe}(\mathrm{BA})_{i}{ }^{(3-i)+}\right]}{\left[\mathrm{Fe}(\mathrm{BA})_{(i-1)}^{(3-(i-1))+}\right]\left[\mathrm{BA}^{-}\right]} &
\end{array}
$$

then, $\quad \log K_{i}=\log \frac{\left[\mathrm{Fe}(\mathrm{BA})_{i}^{(3-i)+}\right]}{\left[\mathrm{Fe}(\mathrm{BA})_{(i-1)}^{(3-(i-1))+}\right]}+\mathrm{p} K_{\mathrm{a}}-\log [\mathrm{HBA}]-\mathrm{pH}$

The acid dissociation constant of benzoylacetone was obtained by $\mathrm{pH}$ titration in DMF. A solution containing $2 \times 10^{-3} M-\mathrm{HBA}$ and $0.1 M-\mathrm{Et}_{4} \mathrm{NGlO}_{4}$ was titrated with $10 \%$ aqueous solution of $\mathrm{Et}_{4} \mathrm{NOH}$ under nitrogen atmosphere. Measurement of $\mathrm{pH}$ was carried out as mentioned before with a glass electrode. In order to elucidate the effect of water which was introduced with the titrant of aqueous $\mathrm{Et}_{4} \mathrm{NOH}$ solution, titrations were carried out in the presence of various concentration of water. When the water content was smaller than 1 vol.\%, the change of the electromotive force of half equivalent point is negligible and is $5 \mathrm{mV}$ in the presence of 2 vol.\% of water. Hence, the effect of the water upon the $\mathrm{p} K_{\mathrm{a}}$ value seems to be small. From these experiment, the $\mathrm{p} K_{\mathrm{a}}$ value of benzoylacetone was determined to be 13.2. Using eq. (16), the consecutive formation constants $\log K_{1}=13.8, \log K_{2}=12.7$ and $\log K=10.9$ were obtained for iron-benzoylacetonate. The over-all stability constant of iron-benzoylacetonate was, therefore, 37.4. This relatively large stability constant of iron-benzoylacetonate in DMF is probably due to the low dielectric constant of this solvent. But there is no available data concerning the stability constant of this compound. Corelation between the $\mathrm{p} K_{\mathrm{a}}$ and the dielectric constant of the solution have been found in dioxan-water and alcohol-water system ${ }^{1112)}$. $\mathrm{p} K_{\mathrm{a}}$ obtained in this experiment is nearly equal to the value in $75 \%$ dioxan-water system. Further work is in progress on the stability constant of iron- $\beta$-diketone chelates in water-DMF system in order to determine the solvent effect on the stability constant of the metal chelate compounds.

\section{Acknowledgment}

The author expresses her deep gratitude to Professor Taitiro Fujinaga of Kyoto University for his kind guidance and encouragement in the course of this work and also to Dr. Kosuke Izutsu for his helpful suggestions and discussions. 


\section{References}

1) A.A. Vlcek, Progress in Inorganic Chemistry, 5, 211 (1963). Interscience, New York ; J. Masek, Talanta, 12, 1173 (1965).

2) I.M. Kolthoff, J. Polarog. Soc., 10, 22 (1964) ; R. Takahashi, Talanta, 12, 1211 (1965) ; S. Wawzonek, ibid., 12, 1229 (1965) ; P.J. Elving and M.S. Spritzer, ibid., 12, 1243 (1965) ; T. Fujinaga, K. Izutsu, T. Arai, K. Takaoka, K. Umemoto, Nippon Kagaku Zasshi, 89, 105 (1968).

3) M. Petek and M. Branica, J. Polarog. Soc., 9, 1 (1963).

4) B. Ćosović and M. Branica, J. Polarog. Soc., 12, 5 (1966).

5) H. Dehn, V. Gutman and G. Scober, Monatsh. Chem., 93, 877(1962).

6) B.K. Afgahn, R.M. Dagnall and K.C. Thompson, Talanta, 14, 715 (1967).

7) R.W. Murray and L.K. Hiller, Jr., Anal. Chem., 39, 1221 (1967).

8) C.D. Ritchie and G.H. Megerle, J. Am. Chem. Soc., 89, 1447 (1967).

9) I.M. Kolthoff and T.B. Reddy, Inorg. Chem., 1, 189 (1962).

10) P.H. Given, M.E. Peover and J. Schoen, J. Chem. Soc., 1958, 2674.

11) L.G. VanUitert, G.G. Haas, W.G. Fernelius and B.E. Douglas, J. Am. Chem. Soc., 75, 455 (1953).

12) P.S. Gentile, M. Cefola and A.V. Celiano, J. Phys. Chem., 67, 1083 (1963).

\section{ジメチルホルムアミド中に拈けるベンゾイルアセトンー鉄 (III) 錯体}

のポーラログラフ的研究

井上竹子

奈良教育大学教育学部 (奈良市高畑町)

シメチルホルムアミド (DMF) 等の非プロン性極性 溶媒は，水に難溶な金属キレート化合物の電気化学的 研究に有用な溶媒と考えられる，今回，著者はトリス (ベンゾイルアセトナト)鉄 $\left.(\mathrm{FeBA})_{3}\right)$ の DMF 中にお ける挙動をポーラログラフ法と定電位電解により検討 した. DMF 中において, $\mathrm{Fe}(\mathrm{BA})_{3}$ は多量の配位子の 存在下で安定に存在し, 滴下水銀電極により可逆的に 還元され $\mathrm{FeBA}_{3}$ - を生ずる. 水の添加によって，直流 波および交流波の波高が減少し，半波電位はより正側 に移行するが, 定電位電解途中のポーラログラムは, 連続した酸化還元波を与え, 電極反応は DMF 中にお ける電極反応と同じように進むと考えられる.

酸の存在下では, 酸濃度の変化に伴って数種の異な
った拡散律速のポーラログラフ波が観察される.とれ らは鉄ベンゾイルアセトンキレートの異なったキレー トイオン種の還元に相当する波であると考えられる. ポーラログラフ波の波高の変化から溶液中に存在する 各キレートイオンの濃度を求め, これらの值と, $\mathrm{pH}$ 滴定によって求められたベンゾイルアセトンの DMF 中における酸解離定数とから, 鉄ベンゾィルアセトン キレートの遂次生成定数を求めるととを試みた， DMF 中におけるベンゾイルアセトンの酸解離定数と して $\mathrm{pKa}=13.2$ の值が得られ，また，DMF 中の鉄 ベンゾイルアセトンキレートの遂次生成定数として, $\mathrm{pK}_{1}=13.8, \mathrm{pK}_{2}=12.7, \mathrm{pK}_{3}=10.9$ の值が得られた。 